\title{
PENERAPAN STRATEGI EXAMPLE NON EXAMPLE UNTUK MENINGKATKAN HASIL BELAJAR SISWA PADA MATA PELAJARAN IPS KELAS V MI MA'ARIF NU 01 SIDAURIP BINANGUN CILACAP TAHUN AJARAN 2015/2016
}

\author{
Khanif Maksum dan Azka Rahmatika \\ Prodi Pendidikan Guru MI STIA Alma Ata \\ Email:khanifmaksum@gmail.com
}

\begin{abstract}
Azka Rabmatika: "The Implementation of example non example strategy to improve students learning outcomes on social science subjects especially the history of hindu, buddhist and islam in Indonesia, in the $5^{\text {th }}$ grade students of MI Maarif NU 01 Sidaurip Binangun Cilacap. Thesis "Study Program Islamic Elementary School Teacher Education, Islamic School of The University of Alma Ata, Yogyakarta, 2016.

This report aims to review the example non example strategy and to know the students study results on Social Science Subject of the the $5^{\text {th }}$ grade students of MI Maarif NU 01 Sidaurip Binangun Cilacap.

This is classroom action research (CAR). There are the $5^{\text {th }}$ grade students of MI Maarif NU 01 Sidaurip Binangun as the research population which are 27 students (16 male and 11 female). The data are collected by observation, interview, tests, and documentation. The data analysis is a qualitative descriptive through several phases namely the data analysis of the learning process, an analysis of the student learning outcome, and making conclusion.

The results of this classroom action research shozes that the implementation of example non example strategy can improve students learning outcomes in social science subjects especially the history of bindu, buddhist and islam in Indonesia, in the $5^{\text {th }}$ grade students of MI Maarif NU 01 Sidaurip Binangun Cilacap. The Minimum Completeness Criteria (KKM) is 70 and the result was increased. Before the class action implemented (pretest) in the first cycle of the percentage of completeness was $18.5 \%$ by number of 5 students and it was increased after class action (post-test) on 55.5\% of completeness or 15 students. In the second cycle obtained the pretest percentage of completeness was $44.4 \%$ or 12 students and post-test percentage of completeness was $92.6 \%$ or 25 students.
\end{abstract}

\section{Keyword: Example Non Example Strategies, Achievements}

\begin{abstract}
Azka Rabmatika:"Penerapan Strategi Example Non Example untuk Meningkatkan Hasil Belajar Siswa Pada Mata Pelajaran Ilmu Pengetabuan Sosial Materi Peninggalan Sejarah dari Masa Hindu Budha dan Islam di Indonesia Kelas V MI Ma'arif NU 01 Sidaurip Binangun Cilacap”. Skripsi. Yogyakarta: Program Studi Pendidikan Guru Madrasah Ibtidaiyah Sekolab Tinggi Ilmu Agama Universitas Alma Ata Yogyakarta, 2016.

Penelitian ini bertujuan untuk mengetabui penerapan strategi Example Non Example dan untuk mengetahui peningkatan hasil belajar IPS siswa kelas VMI Ma'arif NU 01 Sidaurip Binangun Cilacap.

Jenis penelitian ini adalah penelitian tindakan kelas (PTK). Populasi dari penelitian ini adalah siswa kelas VMI Ma'arif NU 01 Sidaurip Binangun Cilacap sejumlab 27 siswa (16 siswa laki-laki dan 11 siswa perempuan. Teknik pengumpulan data dilakukan observasi, wawancara, tes, dan dokumentasi. Analisis data dilakukan secara deskriptif kualitatif melalui beberapa tahapan yaitu analisis data pelaksanaan pembelajaran, analisis hasil belajar siswa, dan penarikan kesimpulan.

Hasil penelitian tindakan kelas ini menunjukkan bahwa penerapan strategi Example Non Example dapat meningkatkan hasil belajar siswa pada mata pelajaran IPS materi Peninggalan sejarab Hindu Budha dan Islam di Indonesia kelas VMI Ma'arif NU 01 Sidaurip Binangun Cilacap memenubi KKM yaitu 70 dan basilnya meningkat. Sebelum dilaksanakan tindakan kelas (pretest) pada siklus I persentase
\end{abstract}


ketuntasan sebesar 18,5\% dengan jumlah 5 siswa dan meningkat setelah dilaksanakan tindakan kelas (postest) memperoleh persentase ketuntasan 55,5\% dengan jumlah 15 siswa. Pada siklus II pretest memperoleh persentase ketuntasan 44,4\% dengan jumlab 12 siswa dan postest memperoleh persentase ketuntasan 92,6\% dengan jumlah 25 siswa.

\section{Keyword: Strategi Example Non Example, Prestasi}

\section{PENDAHULUAN}

Pembelajaran merupakan suatu proses yang dialami siswa untuk mengembangkan suatu gagasan atau pengetahuan, oleh karena itu proses belajar mengajar harus dapat memberikan kesempatan kepada siswa untuk dapat berinteraksi secara aktif. Hal ini, merupakan tantangan yang harus dihadapi guru dalam setiap pembelajaran, untuk mengatasi hal tersebut guru seharusnya memiliki wawasan yang luas, kreatif, dan inovatif dalam proses pembelajarannya.

Indrawati yang dikutip dalam buku Trianto menyatakan bahwa suatu pembelajaran pada umumnya akan lebih efektif bila diselenggarakan melalui model-model pembelajaran yang termasuk rumpun pemrosesan informasi. Hal ini dikarenakan model-model pemrosesan informasi menekankan pada bagaimana seseorang berfikir dan bagaimana dampaknya terhadap cara-cara mengolah informasi. ${ }^{1}$

Berdasarkan hasil wawancara yang dilakukan oleh peneliti kepada guru mata pelajaran IPS, salah satunya yaitu dalam strategi mengajar yang digunakan oleh guru MI Ma'arif NU 01 Sidaurip kurang bervariasi dan masih menggunakan cara klasik. Dalam proses pembelajaran, masih banyak didominasi oleh guru, dan siswa hanya sebagai pendengar dan mencatat, maka siswa lebih cenderung kurang aktif. Untuk penugasan yang diberikan guru adalah tidak lain hanya dari buku paket atau LKS (Lembar Kerja Siswa) yang mana guru tidak membuat masalah tersendiri berkaitan dengan materi supaya siswa dapat lebih berfikir dan tentunya memiliki rasa ingin tahu tentang apa yang dikerjakan. Bahkan bukan hal baru jika siswa mengerjakan tugas, guru tersebut meninggalkan kelas tanpa mengawasinya. ${ }^{2}$ Anggapan ini sangat

${ }^{1}$ Trianto, Mendesain Model Pembelajaran InovatifProgresif, (Jakarta, Kencana: 2009), hlm. 165

${ }^{2}$ Wawancara dengan Bp. Rojikin selaku guru mata mempengaruhi terhadap hasil belajar siswa. Peningkatan hasil belajar siswa membutuhkan strategi supaya bisa menarik perhatian siswa.

Salah satu strategi pembelajaran yang bisa diterapkan yaitu strategi Example Non Example. Strategi Example Non Example merupakan salah satu strategi kooperatif yang mendorong siswa untuk berfikir lebih aktif dan diharapkan dapat membantu siswa dalam memahami materi yang diberikan oleh guru sehingga meningkatkan hasil belajarnya.

Materi Ilmu Pengetahuan Sosial berkaitan dengan sejarah ataupun pengetahuan yang bersifat sosial untuk itu guru diharuskan untuk lebih kreatif dalam menyampaikan materi pelajaran supaya siswa dapat lebih menyerap materi yang dipelajari. Maka strategi Example Non Example merupakan salah satu strategi yang bisa digunakan untuk menyampaikan materi IPS.

Adapun hasil wawancara dengan guru mata pelajaran IPS maka dapat ditulis nilai ulangan harian mencapai 45, sedangkan nilai KKM yaitu 70. Maka dapat dilihat bahwa nilainya masih rendah, masalah yang paling terlihat yaitu mengenai strategi pengajaran yang kurang bervariasi karena lebih berperan pada guru dan siswa hanya menjawab jika ditanya. Dilihat dari segi fasilitas yang ada di MI Ma'arif NU 01 Sidaurip sudah cukup memadai, sepserti media untuk pembelajaran antara lain: LCD, Proyektor, namun masih kurang aktif dan kreatif untuk memanfaatkan media tersebut, salah satunya pada mata pelajaran IPS. Untuk itu perlu adanya strategi pembelajaran yang tepat pada tiap-tiap materi yang akan diajarkan nantinya. Hal seperti itu yang pelu diperhatikan karena akan berdampak pada siswa yang mungkin jenuh dan bosan tidak dengan serius memperhatikan.

pelajaran IPS pada hari Sabtu 22 Agustus 2015 jam 10.05 WIB. 
Penelitian ini terdapat dua Rumusan Masalah. Pertama Bagaimana penerapan strategi Example Non Example pada mata pelajaran IPS materi Peninggalan Sejarah Hindu Budha dan Islam di Indonesia Kelas V di MI Ma'arif NU 01 Sidaurip Binangun Cilacap?. Kedua Apakah Strategi Example Non Example dapat meningkatkan hasil belajar siswa pada mata pelajaran IPS materi Peninggalan Sejarah dari masa Hindu Budha dan Islam di Indonesia Kelas V di MI Ma'arif NU 01 Sidaurip Binangun Cilacap?.

Berdasarkan rumusan malsah tersebut maka tujuan dari penelitian adalah Pertama Untuk mengetahui penerapan strategi Example Non Example pada mata pelajaran IPS materi Peninggalan Sejarah dari masa Hindu Budha dan Islam di Indonesia Kelas V di MI Ma'arif NU 01 Sidaurip Binangun Cilacap. Kedua Untuk mengetahui peningkatan hasil belajar siswa dengan strategi Example Non Example pada mata pelajaran IPS materi Peninggalan Sejarah Hindu Budha dan Islam di Indonesia Kelas V di MI Ma'arif NU 01 Sidaurip Binangun Cilacap.

\section{METODE PENELITIAN Jenis Penelitian}

Jenis penelitian ini menggunakan penelitian tindakan kelas atau Classroom Action Research (CAR). Dalam penelitian ini menggunakan strategi Example Non Example yang bertujuan untuk melihat peningkatan hasil belajar siswa pada mata pelajaran IPS materi Peninggalan Sejarah Hindu Budha dan Islam di Indonesia kelas V MI Ma'arif NU 01 Sidaurip Kecamatan Binangun Kabupaten Cilacap.

PTK memiliki karakteristik tersendiri yaitu masalah yang diangkat adalah masalah yang di hadapi guru di kelas dan adanya tindakan tertentu untuk memperbaiki proses belajar mengajar di kelas. $^{3}$

\section{Desain Penelitian}

Desain penelitian yang digunakan dalam penelitian ini menggunakan penelitian tindakan kelas (PTK), dengan model yang dikemukakan oleh Kemmis \& Mc Taggart. Adapun model

${ }^{3}$ Suharsimi Arikunto, dkk.,Penelitian Tindakan Kelas, (Jakarta, PT. Bumi Aksara: 2007), hlm. 109
PTK dimaksud menggambarkan adanya empat tahapan, dapat dilihat dibawah ini:

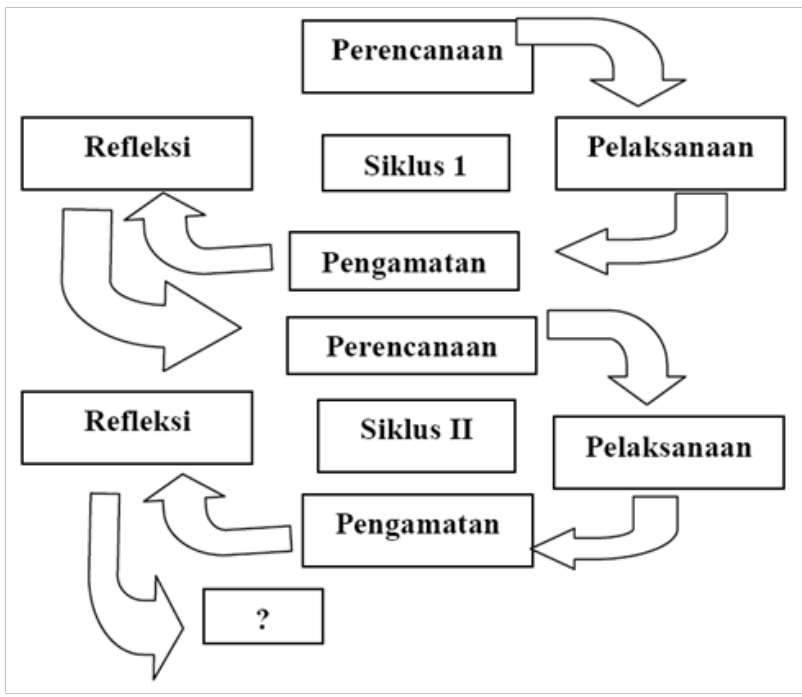

Gambar 1. Tahapan-Tahapan Pelaksanaan PTK ${ }^{4}$

Tahapan siklus tersebut adalah sebagai berikut:

\section{Siklus 1}

Tahap perencanaan (planning)

a) Langkah pertama adalah melakukan perencanaan secara matang dan teliti. Tahap perencanaan yang dilakukan peneliti untuk mempersiapkan semua yaitu:

b) Membuat RPP (Rencana Pelaksanaan Pembelajaran) mata pelajaran IPS materi peninggalan sejarah dari masa Hindu Budha dan Islam di Indonesia kelas $\mathrm{V}$ menggunakan strategi Example non example.

c) Menyiapkan media yang akan digunakan dalam proses belajar mengajar.

d) Membuat dan menyiapkan lembar observasi untuk siswa sebagai pengamatan ketika proses belajar berlangsung.

e) Membuat lembar kerja siswa (LKS).

f) Menyiapkan dokumentasi melalui kamera atau sejenisnya yang digunakan pada saat proses pembelajaran.

Pelaksanaan (Action)

Tahap kedua ini ini adalah pelaksanaan. Pelaksanaan adalah menerapkan apa yang telah

${ }^{4}$ Suharsimi Arikunto, Prosedur Penelitian, (Jakarta, PT RINEKA CIPTA: 2013), hlm. 137 
direncanakan pada satu tahap, yaitu bertindak dikelas dengan menggunakan strategi example non example sesuai dengan RPP yang telah disusun.

\section{Pengamatan (Observation)}

Pada tahap ini dilakukan pengamatan terhadap seluuh proses kegiatan pembelajaran IPS dengan menggunakan strategi Example Non Example. Pada langkah ini peneliti mengamati aktifitas siswa dalam proses pembelajaran, dan penguasaan materi.

\section{Refleksi (reflecting)}

Tahap refleksi ini, merupakan tahapan kegiatan untuk mengemukakan kembali apa yang telah dilakukan. Kegiatan ini akan menjadi intripeksi bagi peneliti untuk mengetahui apa saja kekurangan dan kelebihan pada tiap siklus. Kekurangan pada siklus 1 dapat diperbaiki pada siklus selanjutnya, sedangkan kelebihannya dapat dipertahankan atau dapat ditingkatkan lebih baik.

\section{Siklus II}

Pada tahap kedua ini peneliti melakukan tahapan seperti pada siklus pertama yang dimaksud untuk penyempurnaan dari proses siklus pertama dalam pelaksanaan pembelajaran.

\section{Subjek Penelitian}

Subjek penelitian tindakan kelas ini adalah siswa kelas V MI Ma'Arif NU 01 Sidaurip yang berjumlah 27 siswa, terdiri dari 11 siswa perempuan dan 16 siswa laki-laki serta guru mata pelajaran IPS kelas V yaitu Bapak Rojikin, S.Pd.

\section{Tempat dan Waktu Penelitian}

Penelitian ini dilaksanakan di MI Ma'arif NU 01 Sidaurip Kecamatan Binangun Kabupaten Cilacap. Sedangkan waktu penelitian dilakukan pada bulan Oktober sampai November 2015.

\section{Teknik dan Instrumen Pengumpulan Data}

Peneliti menggunakan beberapa teknik yang digunakan untuk melengkapi ketepatan data. Adapun teknik pengumpulan data yang digunakan yaitu:

\section{Observasi}

Observasimerupakan teknik mengumpulkan data dengan cara mengamati setiap kejadian yang sedang berlangsung dan mencatatnya dengan alat observasi tentang hal-hal yang akan diamati atau diteliti. $^{5}$

Observasi ini dilakukan untuk memperoleh data untuk mengamati siswa saat proses pembelajaran IPS kelas V MI Ma'arif NU 01 Sidaurip Binangun Cilacap. Peneliti menggunakan lembar observasi yang digunakan untuk melihat ketika proses pembelajaan IPS berlangsung.

\section{Wareancara}

Wawancara atau interview dapat diartikan sebagai teknik pengumpulan data dengan menggunakan bahasa lisan baik secara tatap muka ataupun melalui saluran media tertentu. ${ }^{6}$

Sedangkan wawancara yang dilakukan untuk memperoleh data gambaran umum sekolah, letak geografis, sejarah berdiri serta perkembangan, visi, misi, dan tujuan sekolah, struktur organisasi, didapatkan melalui wawancara dengan kepala sekolah yaitu Ibu Sukarni, S.Pd.I.

\section{Tes}

Tes adalah serentetan pertanyaan atau latihan seta alat lain yang digunakan untuk mengatur keterampilan, pengetahuan intelegensi, kemampuan atau bakat yang dimiliki individu atau kelompok. ${ }^{7}$

Tes digunakan untuk mengukur kemampuan dasar dan peningkatan hasil belajar siswa dengan soal-soal pretest untuk mengetahui kemampuan awal siswa sebelum dilakukan tindakan dan postest terkait materi yang telah diajarkan sebagai alat mengevaluasi yang nantinya dapat mengetahui hasil belajar siswa setelah dilakukan tindakan.

\section{Dokumentasi}

Dokumentasi adalah cara mengumpulkan data melalui peninggalan tertulis, seperti arsiparsip dan termasuk juga buku- buku tentang pendapat, teori, dalil atau hukum-hukum, dan

5ina Sanjaya, Penelitian Tindakan..., hlm. 86

${ }^{6}$ Suharsimi Arikunto, Prosedur Penelitian..., hlm. 274

${ }^{7}$ Suharsimi Arikunto, Prosedur Penelitian Suatu

Pendekatan Praktik( Jakarta, Rineka Cipta: 2006), hlm. 193 
lain- lain yang berhubungan dengan masalah penelitian. ${ }^{8}$

Dalam penelitian ini, dokumentasi digunakan untuk mengumpulkan data kegiatan pembelajaran IPS dengan strategi Example Non Example siswa kelas V MI Ma'arif NU 01 Sidaurip Binangun Cilacap.

\section{Instrumen Pengumpulan Data}

Instrumen penelitian adalah alat atau fasilitas yang digunakan oleh peneliti dalam mengumpulkan data agar pekerjaannya mudah dan hasilnya lebih baik, dalam arti cermat, lengkap, sistematis sehingga lebih mudah diolah. ${ }^{9}$

Dalam penelitian ini menggunakan instumen penelitian sebagai berikut:

\section{Lembar observasi}

Lembar observasi berisi beberapa daftar kegiatan yang akan diamati observer dengan memberikan tanda pada kolom yang telah disediakan. Lembar observasi terdiri dari lembar observasi guru dan lembar observasi siswa. Lembar obsevasi dibuat peneliti untuk mengamati perilaku siswa dalam proses pembelajaran.

\section{Wawancara}

Pedoman wawancara berisi daftar petanyaan terstruktur yang ditanyakan kepada kepala sekolah Ibu Sukarni, S.Pd.I, guru mata pelajarn IPS Bapak Rojikin, S.Pd, maupun siswa.

\section{Lembar Tes}

Dalam penelitian ini, peneliti menggunakan tes dengan pretest dan postest. Bentuk soal tes tertulis berupa soal-soal yang dikerjakan secara individual. Dalam hal ini, tes sebagai alat evaluasi untuk mengetahui peningkatan hasil belajar siswa setelah dilakukan tindakan.

\section{Dokumentasi}

Dokumentasi digunakan untuk mengetahui suasana kelas saat proses pembelajaran IPS

\footnotetext{
${ }^{8}$ Margono, Metodologi Penelitian Pendidikan, (Jakarta, Asdi Mahasatya: 2000), hlm. 181

${ }^{9}$ Suhardjono, Penelitian Tindakan Kelas (Sebagai Kegiatan Pengembangan Profesi Guru), (Jakarta, Bumi Aksara: 2007), hlm.160
}

materi Peninggalan Sejarah dari masa Hindu Budha dan Islam di Indonesia kelas V MI Ma'arif NU 01 Sidaurip Binangun Cilacap berlangsung menggunakan strategi Example Non Example.

\section{Keabsahan Data \\ Uji Validitas Instrumen}

Pada penelitian ini menggunakan validitas isi. Isi tes harus sesuai dengan materi yang ingin diukur dan diujikan. ${ }^{10}$

\section{Mengetabui peningkatan hasil belajar siswa}

Untuk mengetahui meningkatnya hasil belajar dilihat dari pretest dan postest. Berikut adalah rumus untuk menghitung banding dari hasil tiap siklus.

$$
P=\frac{f}{N} \times 100 \%
$$

Keterangan:

F : Frekuensi yang sedang dicari presentasenya $\mathrm{N}$ : Number of Cases (jumlah frekuensi/banyaknya individu)

P : Angka presentase ${ }^{11}$

\section{Teknik Analisis Data}

Menganalisis data adalah suatu proses mengolah dan menginterpretasi data dengan tujuan untuk mendudukan berbagai informasi sesuai dengan fungsinya hingga memiliki makna dan arti yang jelas sesuai dengan tujuan penelitian. ${ }^{12}$ Adapun langkah-langkah analisis data sebagai berikut:

1. Analisis data pelaksanaan pembelajaran IPS kelas V dengan strategi Example Non Example MI Ma'arif NU 01 Sidaurip Binangun Cilacap. Data yang dianalisis dalam pelaksanaan pembelajaran tersebut terdapat dalam lembar observasi yang mencakup aktifitas guru, aktfitas siswa, dan proses pembelajaran yang dianalisis secara deskriptif.

2. Analisis hasil belajar siswa kelas $\mathrm{V}$ mata pelajaran IPS dengan strategi Example Non Example MI Ma'arif NU 01 Sidaurip Binangun Cilacap.

${ }^{10}$ Djemari Mardapi, Teknik Penyusunan Instrumen Tes dan Non Tes, (Yogyakarta, Mitra Cendekia: 2008), hlm. 19

${ }^{11}$ Anas Sudijono, Statistik Pendidikan (Jakarta, PT Raja Grafindo Persada: 2008), hlm.43

${ }^{12}$ Wina Sanjaya, Penelitian Tindakan ..., hlm. 106 
Untuk menganalisis hasil belajar siswa peneliti menggunakan data dari pretest dan postest dari setiap siklusnya. Siswa dikatakan meningkat hasil belajarnya jika terjadi peningkatan persentase rata-rata hasil tes.

\section{Kesimpulan}

Data yang telah diperoleh setelah dianalisis kemudian diambil kesimpulannya pada tiap siklusnya yang telah dilakukan tindakan yaitu penerapan strategi Example Non Example, apakah hasil belajar siswa meningkat atau dapat tercapai, jika belum tercapai maka dilakukan ulang dan jika sudah tercapai maka penelitian dianggap sudah cukup dalam artian dapat dihentikan.

\section{HASIL PENELITIAN}

Pelaksanaan tindakan dalam penelitian tindakan kelas ini dilaksanakan dengan tahap awal yaitu obsevasi dilakukan pada tanggal 2831 Oktober 2015, kegiatan ini dilakukan untuk mengetahui perolehan nilai sebelum dilakukan tindakan pada tiap siklus, supaya mengetahui dimana kesulitan belajar siswa dalam menerima materi khususnya pada mata pelajaran Ilmu Pengetahuan Sosial dan bagaimana cara guru dalam melakukan proses pembelajaran.

Dari hasil observasi dan wawancara kegiatan pembelajaran IPS materi Peninggalan Sejarah dari masa Hindu Budha dan Islam di Indonesia kelas V MI Ma'arif NU 01 Sidaurip Binangun Cilacap yaitu sebagai berikut:

1. Siswa mengalami kesulitan dalam proses pembelajaran IPS

2. Guru menggunakan metode pembelajaran ceramah dan tanya jawab dalam kegiatan pembelajaran.

3. Guru melakukan tanya jawab jika ada siswa yang bertanya.

4. Siswa tidak aktif dalam kegiatan pembelajaran IPS yakni siswa hanya mendengarkan dan diam.

5. Strategi yang dipakai belum efektif untuk meningkatkan hasil belajar siswa dalam mata pelajaran IPS materi Peninggalan Sejarah dari Masa Hindu Budha dan Islam di Indonesia.

Pelaksanaan penelitian tindakan kelas dilakukan peneliti yang tediri dari dua siklus dan tiap siklus dilaksanakan 3 pertemuan yang didalamnya termasuk kegiatan Pretest untuk mata pelajaran Ilmu Pengetahuan Sosial (IPS) materi Peninggalan Sejarah dari Masa Hindu Budha dan Islam di Indonesia menggunakan strategi Example Non Example. Berdasarkan hasil penelitian di atas, maka penelitian dapat dijelaskan sebagai berikut:

Penerapan strategi Example Non Example dalam mata pelajaran IPS materi Peninggalan sejarah dari masa Hindu Budha dan Islam di Indonesia kelas V MI Ma'arif NU 01 Sidaurip Binangun Cilacap.

Penelitian tindakan kelas ini dilakukan di MI Ma'arif NU 01 Sidaurip Binangun Cilacap dengan jumlah siswa sebanyak 27. Penelitian tindakan kelas pada mata pelajan IPS materi Peninggalan sejarah dari masa Hindu Budha dan Islam di Indonesia dengan stategi Example Non Example telah dilaksanakan dalam 2 siklus.

Siklus I terdiri dari 3 pertemuan yaitu pertemuan 1 dilaksanakan pada hari senin tanggal 2 November 2015 jam pelajaran 5-6 pukul 10.0011.10 WIB. Petemuan ke-2 dilaksanakan selasa tanggal 3 November 2015 jam pelajaran 5-6 pukul 10.00-11.10 WIB dan pertemuan ke-3 hari kamis tanggal 5 November 2015 jam pelajaran 5-6 pukul 10.00-11.10 WIB.

Sedangkan siklus II terdiri dari 3 petemuan yaitu pertemuan 1 dilaksanakan hari kamis tanggal 15 November 2015 jam pelajaran 5-6 pukul 10.0011.10 WIB, pertemuan ke-2 dilaksanakan hari senin tanggal 16 November 2015 jam pelajaran 5-6 pukul 10.00-11.10 WIB, dan pertemuan ke-3 pada hari rabu, 18 November 2015 jam pelajaran 5-6 pukul 10.00-11.10 WIB. Dengan demikian penerapan strategi Example Non Example pada siklus I dan sukuls II dapat diuraikan sebagai berikut:

\section{Gambar-gambar peninggalan sejarah}

Peneliti menggunakan gambar untuk menjelaskan dan siswa memegang sendiri-sendiri supaya mereka tetap fokus dalam mendengarkan penjelasan. Peneliti juga menempel gambar dipapan tulis dan siswa ditunjuk untuk maju kedepan menjelaskan ulang dan mengisi gambar tokoh yang belum diketahui. 


\section{Media proyektor}

Peneliti menggunakan media ini supaya siswa tidak bosan dengan penjelasan yang hanya berpacu pada buku, dan siswa lebih memperhatikan.

\section{Melakukan tanya jarwab}

Peneliti selalu menggunakan tanya jawab setelah penjelasan dan mengajak siswa terus aktif dalam pembelajaan.

\section{Penelitian}

Pebeliti melakukan pemainan di saat sela waktu setelah penjelsan supaya siswa tidak bosan dan tetap semangat dalam pembelajaran.

\section{Diskusi}

Diskusi dilakukan supaya siswa lebih aktif dalam berkelompok dan dapat tukar pendapat dan merumuskan masalah dengan bersama yang nantinya dalam pembelajaran siswa lebih tanggap untuk bertanya.

Respon siswa dalam proses pembelajarannya sangat antusias dengan dilaksanakannya strategi Example Non Example. Dapat dilihat bagaimana siswa menjawab dan aktif. Dengan menggunakan strategi tersebut dapat meningkatkan keaktifan siswa dalam pembelajaran. Siswa yang sebelumnya hanya menjadi pendengar, sekarang menjadi semangat untuk memperoleh hasil.

Secara keseluruhan pembelajaran IPS kelas V materi Peninggalan Sejarah dari Masa Hindu Budha dan Islam di Indonesia dengan menggunakan strategi Example Non Example dapat digunakan dalam proses pembelajaran untuk meningkatkan hasil belajar siswa yaitu pada siklus I memperoleh nilai rata-rata 71,2 dengan persentase ketuntasan $55,5 \%$ dan siklus II memperoleh nilai rata-rata 88,7 dengan persentase ketuntasan 92,6\%.

Berdasarkan nilai yang sudah diuraikan bahwa strategi ini bisa diterapkan dan dapat meningkatkan hasil belajar siswa dengan media yang digunakan peneliti yaitu diantaranya menggunakan gambar-gambar dan menjelaskan materi dengan proyektor terkait dengan materi supaya siswa lebih paham, dapat membedakan, dan mengetahui peninggalan- peninggalan dan tokoh-tokoh dari masa Hindu Budha dan Islam di Indonesia. Dengan menerapkan strategi Example Non Example dapat menggunakan berbagai media tergantung materi dan mata pelajaran yang diajarkan.

Strategi Example Non Example yang sudah diterapkan peneliti dapat meningkatkan hasil belajar, keaktifan siswa dalam proses pembelajaran dan membuat siswa memiliki rasa ingin tahu lebih dari materi yang dijelaskan.

Peningkatan hasil belajar siswa pada mata pelajaran IPS materi peninggalan sejarah dari masa Hindu Budha dan Islam di Indonesia kelas V MI Ma'arif NU 01 Sidaurip Binangun Cilacap.

Berdasarkan hasil pelaksanaan tindakan kelas siklus I dan siklus II kegiatan pembelajaran menggunakan strategi Example Non Example pada mata pelajaran IPS materi Peninggalan sejarah dari masa Hindu Budha dan Islam di Indonesia kelas V MI Ma'arif NU 01 Sidaurip Binangun Cilacap dapat dikatakan berhasil karena terjadi peningkatan hasil belajar siswa. Berikut adalah nilai hasil belajar siswa pada mata pelajarn IPS materi Peninggalan sejarah dari masa Hindu Budha dan Islam di Indonesia kelas V MI Ma'arif NU 01 Sidaurip Binangun Cilacap.

Dari tabel 1 dan grafik 2 terdapat peningkatan nilai rata-rata pada tiap siklus. Siklus I memperoleh nilai rata-rata pretest 60 dengan persentase ketuntasan $18,51 \%$ dan postest memperoleh ratarata 71,2 dengan persentase ketuntasan 55,5\%. Sedangkan siklus II pada pretest memperoleh nilai rata-rata 65 dengan persentase ketuntasan $44,44 \%$ dan postest memperoleh rata-rata 88,7 dengan persentase ketuntasan 92,6\%.

Dari keseluruhan data diatas, tujuan penelitian telah berhasil pada siklus II, sehingga penelitian dianggap telah tercapai dan memenuhi KKM yaitu 70 . Hasil penelitian menunjukan adanya peningkatan hasil belajar pada mata pelajaran Ilmu Pengetahuan Sosial kelas V materi Peninggalan Sejarah dari Masa Hindhu Budha dan Islam di Indonesia menggunakan strategi Example Non Example, pada siklus I posttest memperoleh ketuntasan $55,5 \%$ dan siklus II memperoleh ketuntasan $92,6 \%$. 
Tabel 1. Hasil Belajar Siklus I dan Siklus II

\begin{tabular}{|c|c|c|c|c|c|}
\hline \multirow{2}{*}{ No. } & \multirow{2}{*}{ Nama Siswa } & \multicolumn{2}{|c|}{ Siklus I } & \multicolumn{2}{|c|}{ Siklus II } \\
\hline & & Pretest & Postest & Pretest & Postest \\
\hline 1. & Adiba Riyadh A & 65 & 60 & 70 & 90 \\
\hline 2. & Aulia Nafis Sabrina & 55 & 70 & 80 & 95 \\
\hline 3. & Ain Fazila & 62 & 65 & 55 & 75 \\
\hline 4. & Anam Khoirun M & 60 & 90 & 95 & 95 \\
\hline 5. & Arif Tajuddin Anam & 60 & 60 & 75 & 95 \\
\hline 6. & Aryani D & 50 & 65 & 60 & 80 \\
\hline 7. & Endah Fatihah & 65 & 65 & 65 & 95 \\
\hline 8. & Faturrahman & 60 & 65 & 55 & 95 \\
\hline 9. & Inayah Laylatuz Z & 70 & 65 & 65 & 95 \\
\hline 10. & Khoirul Arif & 60 & 65 & 60 & 100 \\
\hline 11. & Miftahurrizal & 62 & 60 & 60 & 100 \\
\hline 12. & Muhammad M & 65 & 70 & 50 & 85 \\
\hline 13. & Novrida Utami & 45 & 70 & 45 & 65 \\
\hline 14. & Nur Laela Hasni & 70 & 90 & 70 & 90 \\
\hline 15. & Okta Zuhri Gagah R & 75 & 80 & 80 & 90 \\
\hline 16. & Puji Rahayu & 50 & 65 & 55 & 60 \\
\hline 17. & Rangga Rizky J & 62 & 75 & 70 & 85 \\
\hline 18. & Rifki Tegar R & 70 & 75 & 75 & 85 \\
\hline 19. & Rio Eka Prayogi & 60 & 65 & 65 & 85 \\
\hline 20. & Reva Ismi Lutfiana & 65 & 80 & 60 & 75 \\
\hline 21. & Satrima & 60 & 80 & 70 & 85 \\
\hline 22. & Tiara Amelia & 60 & 70 & 70 & 100 \\
\hline 23. & Tegar Muktiadi & 70 & 90 & 75 & 90 \\
\hline 24. & Teji Indra Saputra & 65 & 70 & 60 & 95 \\
\hline 25. & Toha Ma'ruf A & 50 & 75 & 55 & 90 \\
\hline 26. & Triasih Puji Lestari & 55 & 85 & 75 & 100 \\
\hline 27. & Yazid Isnan R & 50 & 55 & 40 & 100 \\
\hline & Jumlab & 1641 & 1925 & 1755 & 2395 \\
\hline & Rata-rata & 60 & 71,2 & 65 & 88,7 \\
\hline & Tuntas $\geq 70$ & $18,5 \%$ & $55,5 \%$ & $44,4 \%$ & $92,6 \%$ \\
\hline & Belum Tuntas $\leq 70$ & $81,4 \%$ & $44,4 \%$ & $55,5 \%$ & $7,40 \%$ \\
\hline
\end{tabular}

\section{KESIMPULAN}

Berdasarkan hasil penelitian tindakan kelas (PTK) yang peneliti lakukan dengan judul "penerapan strategi Example Non Example untuk meningkatkan hasil belajar siswa pada mata pelajaran IPS materi Peninggalan Sejarah dari Masa Hindu Budha dan Islam di Indonesia kelas V MI Ma'arif NU 01 Sidaurip Binangun Cilacap Tahun Ajaran 2015/2016, maka peneliti memperoleh kesimpulan sebagai berikut:

1. Penerapan strategi Example Non Example pada mata pelajaran IPS kelas V materi Peninggalan Sejarah dari Masa Hindu Budha dan Islam di Indonesia di MI Ma'arif NU 01 Sidaurip, yaitu berjalan dengan lancar dan dilaksanakan dengan menggunakan gambar-gambar sejarah peninggalan Hindu Budha dan Islam di Indonesia, media proyektor, diskusi, dan tanya jawab.

2. Peningkatan hasil belajar siswa dengan menggunakan strategi Example Non Example kelas V di MI Ma'arif NU 01 Sidaurip, hal ini 


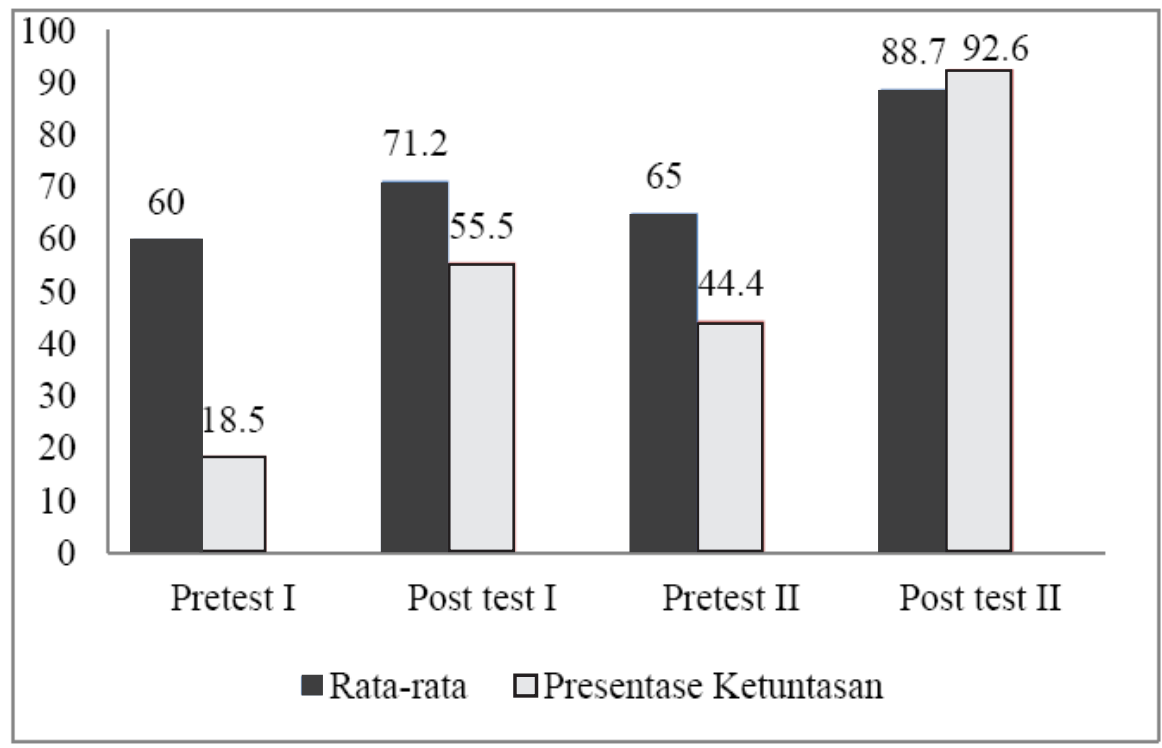

Gambar 2. Grafik Ketuntasan Siklus I dan Siklus II

dapat dibuktikan dari persentase siswa yang mendapat nilai diatas KKM mata pelajaran Ilmu Pengetahuan Sosial materi Peninggalan Sejarah dari masa Hindu Budha dan Islam di Indonesia sebelum dilaksanakan tindakan kelas (pretest) siklus I persentase ketuntasan sebesar 18,5\% dengan jumlah 5 siswa dan meningkat setelah dilaksanakan tindakan kelas (postest) memperoleh persentase ketuntasan 55,5\% dengan jumlah 15 siswa. Pada siklus II pretest memperoleh persentase ketuntasan 44,4\% dengan jumlah 12 siswa dan postest memperoleh persentase ketuntasan 92,6\% dengan jumlah 25 siswa. Demikian hasil dari tiap siklus yang telah diterapkan terbukti meningkatkan hasil belajar siswa dan telah memenuhi KKM yaitu 70.

\section{DAFTAR PUSTAKA}

Agus Suprijono. 2010. Cooperative Learning. Yogyakarta: Pustaka Pelajar. 2009. Cooperative Learning. Yogyakarta: Pustaka Belajar.

Anas Sudijono. 2008. Statistik Pendidikan. Jakarta: PT Raja Grafindo Persada.

Djemari Mardapi. 2008. Teknik Penyusunan Instrumen Tes dan Non Tes. Yogyakarta: Mitra Cendekia.

Eko Putro Widoyoko. 2009. Evaluasi Program Pembelajaran. Yogyakarta: Pustaka Belajar.
Hamzah B. Uno. 2006. Perencanaan Pembelajaran. Jakarta: Bumi Aksara.

Hamdani. 2011. Strategi Belajar Mengajar. Bandung: Pustaka Setia.

Jamil Suprihatiningrum. 2013. Strategi Pembelajaran Teori dan Aplikasi. Jogjakarta: Ar-Ruzz Media.

Martinis Yamin. 2013. Strategi dan Metode dalam Model Pembelajaran. Jakarta: GP Press Group.

Margono. 2000. Metodologi Penelitian Pendidikan. Jakarta: Asdi Mahasatya.

Miftahul Huda. 2013. Model-Model Pengajaran dan Pembelajaran. Yogyakarta: Pustaka Pelajar.

Suharsimi Arikunto. 2010. Prosedur Penelitian Suatu Pendekatan Praktik. Jakarta: Rineka Cipta.

dkk. 2007. Penelitian Tindakan Kelas. Jakarta: PT. Bumi Aksara.

1987. Dasar-dasar Evaluasi Pendidikan.

Jakarta: Bumi Aksara.

. 2013. Prosedur Penelitian. Jakarta: PT RINEKA CIPTA.

2006. Prosedur Penelitian Suatu

Pendekatan Praktik. Jakarta: Rineka Cipta.

Sugiyono. 2012. Statistika Untuk Penelitian. Bandung: Alfabeta

2010. Statistik Untuk Penelitian. Bandung:

Alfabeta 
Suhardjono. 2007. Penelitian Tindakan Kelas (Sebagai Kegiatan Pengembangan Profesi Guru). Jakarta: Bumi Aksara.

2010. Metode Penelitian Pendidikan Pendekatan Kuantitatif, Kualitatif, dan R\&D. Bandung: Alfabeta.

.2010. Statistik untuk Penelitian. Bandung: Alfabeta.

Syaiful Bahri Djamarah dan Azwan Zain. 1997. Strategi Belajar Mengajar. Jakarta: PT. Rineka Cipta.

2010. Strategi Belajar Mengajar. Jakarta:

PT Rineka Cipta.
Trianto. 2009. Mendesain Model Pembelajaran Inovatif-Progresif. Jakarta: Kencana. 2010. Model Pembelajaran Terpadu. Jakarta: PT Bumi Aksara.

Utomo Dananjaya. 2010. Media Pembelajaran Aktif. Bandung: Nuansa.

Wina Sanjaya. 2008. Strategi Pembelajaran Berorientasi Proses Pendidikan. Jakarta: Kencana Prenada Media.

. 2011. Penelitian Tindakan Kelas. Jakarta: Kencana Prenada Media Group. 